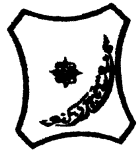

Bayero Journal of Pure and Applied Sciences, 9(2): 95 - 101

Received: June, 2016

Accepted: October, 2016

ISSN $2006-6996$

\title{
EFFECTS OF AQUEOUS EXTRACT OF Allium cepa (Red Onion) ON OVALBUMIN- INDUCED ALLERGIC ASTHMA IN WISTAR RATS
}

\author{
${ }^{1}$ Dawud, F.A., ${ }^{1}$ Dubo, A. B., ${ }^{2}$ Yusuf, N. W. and ${ }^{3}$ Umar, I .A. \\ ${ }^{1}$ Department of Human Physiology Ahmadu Bello University, Zaria, Nigeria. \\ ${ }^{2}$ Department of Human Physiology, Faculty of Basic Sciences, Bayero University Kano, Nigeria. \\ ${ }^{3}$ Department of Biochemistry Ahmadu Bello University, Zaria, Nigeria. \\ *Correspondence author: fadawud@yahoo.com 08182988120
}

\begin{abstract}
Asthma is a chronic inflammatory disease of airways that involves inflammatory cells and mediators to elicit inflammatory response. Allium cepa is a common plant used as condiment and has anti-inflammatory, antifungal and antibacterial properties. The aim of this study was to investigate the effect of aqueous extract of Allium cepa (EAC) on leucocytes infiltration and lung histology in Ovalbumin-induced allergic asthma in Wistar rats. Allergic asthma was induced in rats by systemic sensitization with ovalbumin (OVA) via intraperitoneal (i.p.) injections followed by intranasal (i.n.) challenge. Extract of Allium cepa at doses of $150 \mathrm{mg} / \mathrm{kg}$ and $300 \mathrm{mg} / \mathrm{kg} \mathrm{b.w.} \mathrm{;} \mathrm{and}$ dexamethasone $(1 \mathrm{mg} / \mathrm{kg})$ were given to the treated groups. The asthmatic group showed a significant $(p<0.05)$ increase in number of eosinophil and lymphocyte in the Blood and bronchoalveolar fluid $(B A L F)$, which was significantly $(p<0.05)$ decreased in Allium cepa treated groups. Histological assessment of the lung tissue showed various degrees of inflammation in all OVA-induced animals, but a decreased inflammation was observed in those treated with Allium cepa and dexamethasone. It is therefore, concluded that aqueous extract of Allium cepa reduced cellular infiltration and lung inflammation of allergic asthmatic Wistar rats.
\end{abstract}

Key words: Asthma, Ovalbumin, Allium cepa, Leucocytes, Rat

\section{INTRODUCTION}

Asthma belongs to the category of obstructive pulmonary diseases (OPD). These diseases are characterised by difficulty in expiration due to decreased intrapulmonary pressure (Mitchell et al., 2011). A higher prevalence of asthma among Nigerian adolescents and adults compared with regional and global averages (Musa and Aliyu, 2014).

Approximately two-thirds of asthma cases are allergic, characterised by excessive production of IgE and associated with antigen-antibody induced inflammatory cascade, bronchoconstriction, increased mucus production and mucosal edema (Manohar and selvakumar, 2012). The infiltration of leucocytes into the lungs with release of mast cells bronchoconstrictor mediators and elevated level of immunoglobulin $E$ (IgE), stimulate allergic inflammation (Chaudhari et al., 2011).

Allium cepa (Red onion) is one of the oldest cultivated plants used both as food, condiment and for medicinal purposes (Lanzotti, 2006). Onion is cultivated all over the world especially in Europe, Asia, North America and Africa (Nasri et al., 2012). In Nigeria, onion is cultivated widely in the northern part where it is commonly called Albasa.

Onions are known to possess medicinal properties from ancient time. Humans have used them for centuries for medicinal purposes. Researches have shown that Allium cepa have some therapeutic properties: lowers blood cholesterol levels
(Ghalehkhandi et al., 2012); hypoglycemic activity (Ogunmodede et al., 2012); hepatoprotective effect (Ozougwu and Eyo, 2014); analgesic, antiinflammatory and antioxidant activity (Nasri et al., 2012).

Traditional medicinal practitioners in Nigeria recommend the use of Allium cepa for relief of epileptic seizures, asthmatic symptoms etc. However, there is paucity of scientific information on the specific role of onion in allergic asthma.

A simple and sensitive animal model of asthma is using ovalbumin sensitization followed by challenge. Allergic response is observed in lungs 24 hours after OVA challenge (Manoharet et al., 2012). Rats exhibit features of airway allergy and allergic asthma when exposed to allergen that is similar to that of humans (Moffet et al., 2003). This study therefore investigates the effects of aqueous extract of Allium cepa (EAC) on cellular infiltration in ovalbumin-induced allergic asthma in Wistar rats.

\section{MATERIALS AND METHODS}

\section{Drugs and chemicals}

Ovalbumin (Mayer and Baker Itd. Bagenham, England), Aluminium hydroxide (BDH chemicals Itd. Poole, England), Dexamethasone $(1 \mathrm{mg} / \mathrm{kg}$, Hubei Tianyao Pharmaceutical Co. Ltd), Ketamin hydrochloride $(50 \mathrm{mg} / \mathrm{kg})$. 


\section{Animals}

Twenty-five Wister strain rats $(130-150 \mathrm{~g})$ of both sexes were allowed to acclimatize for two weeks before experiment. They were maintained on a commercial poultry feed and water ad libitum.

\section{Collection of Plant Material and Extraction}

Fresh red onion bulbs were purchased from Samaru market Zaria, Kaduna state Nigeria in the month of August, 2015. The botanical identification was done at the herbarium unit of Biological Science Department, Ahmadu Bello University, Zaria with voucher number 2196. Onion bulbs were washed, cut into small pieces and homogenized. The resulting mixture was soaked in $1 \mathrm{~L}$ of distilled water and was allowed to stand for 24 hours with intermittent shaking. The mixture was then filtrated and the filtrate evaporated to dryness. The dried extract was then stored at $4^{\circ} \mathrm{C}$ before use.

\section{Experimental Design}

The twenty-five (25) Wistar rats were randomly divided into five (5) groups as follows:

Group1: normal saline only intraperitoneally

Group2: $200 \mathrm{mg}$ ovalbumin (OVA) intranasally only

Group3: 200mg OVA intranasally $+150 \mathrm{mg} / \mathrm{kg}$ Extract Allium cepa intraperitoneally

Group4: $200 \mathrm{mg}$ OVA intranasally $+300 \mathrm{mg} / \mathrm{kg}$ Extract Allium cepa intraperitoneally

Group5: 200mg OVA intranasally $+1 \mathrm{mg} / \mathrm{kg}$ dexamethasone intraperitoneally

The animals in group 1 were given an intraperitoneal injection of normal saline $(0.9 \% \mathrm{NaCl})$ on days 0,7 and 14. Groups 2-5 were sensitized with intraperitoneal injection of ovalbumin followed by ovalbumin challenge. An hour before each OVA challenge, the animals in group 3 and 4 were given intraperitoneal injection of extract Allium cepa $150 \mathrm{mg} / \mathrm{kg}$ and $300 \mathrm{mg} / \mathrm{kg}$ body weight respectively, while group 5 were given intraperitoneal injection of Dexamethasone (1 $\mathrm{mg} / \mathrm{kg}$ body weight).

\section{Ovalbumin Sensitization and Ovalbumin Challenge}

Animal in groups 2-5, were sensitized by intraperitoneal injection of ovalbumin $(20 \mathrm{mg} / \mathrm{kg})$ in aluminium hydroxide $(100 \mathrm{mg} / \mathrm{kg})$ in normal saline on days 0, 7 and 14 (i.p) (Russo et al., 2001). Three (3) days after ovalbumin sensitization, all animals in groups 2-5 were challenged with $50 \mu \mathrm{L}$ of ovalbumin at $200 \mathrm{mg}$ via intra nasal route for four consecutive days (Days 18, 19, 20 and 21). The control group (non-sensitized) were treated with aluminium hydroxide and instillation of normal saline (Agbonon et al., 2005).

\section{Collection of Broncho Alveolar Fluid (BALF) and differencial cell count.}

The rats were anesthetised with Ketamin hydrochloride $(50 \mathrm{mg} / \mathrm{kg})$ at $0.45 \mathrm{ml} / \mathrm{rat}$ via intraperitoneal route 24 hours after the last challenge $\left(22^{\text {nd }}\right.$ day). Broncho Alveolar lavage procedure was performed in tracheotomised trachea. The anterior end of the left trachea was tied with a thread and the trachea was cannulated, $2 \mathrm{ml}$ of normal saline was injected into the cannulated trachea and was aspirated 10 seconds later as BALF). The procedure was repeated and the collected BALF was centrifuged to separate the cells from the supernatant (Chaudhari et al., 2011) Differential cell counts were performed after staining with Giemsa solution. About 300 cells were counted and were differentiated by general leukocyte morphology to determine the number of cellular infiltration

\section{Collection of Blood sample and differencial cell} count

Blood was collected by cardiac puncture and was kept in EDTA tube which was later used for systemic differential white blood cell count. A magnification of times 100 was used to count the differential white blood cells (Lewis et al., 2008).

\section{Histological Examination}

Left Lung was removed completely from the chest cavity, and fixed with $10 \%$ neutral buffered formalin and the histological preparation and analysis, was carried out by a trained histologist at the histological section in the Department of Human Anatomy, A. B. U. Zaria, Histological sections were viewed with magnification of $\times 100$.

\section{Statistical analysis}

All results were expressed as mean \pm standard errors of the mean (SEM). Statistical significance of differences was assessed by one-way analysis of variance (ANOVA) followed by Tukey's post hoc test. The mean difference between cell count in blood and in BALF was assessed by independent-sample T-test. In all cases, $P<0.05$ was considered statistically significant. Statistical Package for Social Science (SPSS) version 15 was used for the analysis.

\section{Results and Discussion}

There was a statistical significant $(P<0.05)$ increase in neutrophil, eosinophil, and lymphocyte counts in the blood of ovalbumin-induced allergic asthma in Wistar rats (Table 1). Administration of $150 \mathrm{mg} / \mathrm{kg}$ extract Allium cepa $(\mathrm{EAC})$ caused a significant $(\mathrm{P}<0.05)$ decrease in only the neutrophil count, but treatment with $300 \mathrm{mg} / \mathrm{kg}$ EAC or Dexamethasone (DEX) $1 \mathrm{mg} / \mathrm{kg}$, significantly $(\mathrm{P}<0.05)$ decreased both eosinophil and lymphocyte counts. Monocytes count was significantly $(P<0.05)$ decreased in OVA group, while treatment with $150 \mathrm{mg}$ EAC reversed the effect but was significantly $(P<0.05)$ decreased in $D E X$ treated group. There was no significant change in basophil count in all the groups (Table 1 ).

The development of asthma in rats is confirmed by an increase in inflammatory mediators in the blood, bronchoalveolar lavage fluid and change in histology of the lung tissue (Kucharewicz et al., 2008). In this study, the increase in eosinophil and lymphocyte counts in blood of OVA-induced allergic asthma model is indicative of inflammatory response. Sensitization followed by challenge with OVA in OVA-induced asthma model in Wistar rats is known to increase inflammatory mediators like eosinophils, neutrophils, T-lymphocytes, monocytes (Kucharewicz et al., 2008). Study by Zhang et al. (2014) showed that the blood eosinophil/lymphocyte ratio and eosinophil/neutrophil ratio are increased in eosinophilic asthma. 
The decreases of inflammatory mediators with Allium cepa demonstrate an anti-inflammatory property of the plant that was consistent with the effect of Dexamethasone, a standard antiasthma drug.

Result in table 2, showed the effects of aqueous extract of Allium cepa on WBC differential count in bronchoalveolar fluid (BALF) of ovalbumin-induced allergic asthma in Wistar rats. The eosinophil and lymphocyte count in OVA (Asthma) group were significantly $(P<0.05)$ higher compared with the control (Non-sensitized) group. Whereas treatment with EAC at $150 \mathrm{mg} / \mathrm{kg}$ and $300 \mathrm{mg} / \mathrm{kg}$ significantly $(\mathrm{P}<0.05)$ decreased both eosinophil and lymphocyte count which was similar to the effect of the standard drug Dexamethasone $(1 \mathrm{mg} / \mathrm{kg})$. There was no significant $(P<0.05)$ change in monocyte count in all the groups. The effect of dexamethasone on cell count in BALF and blood is consistent with study reported by Salama et al. (2012).

The increase in eosinophil and lymphocyte counts in bronchoalveolar lavage fluid (BALF) of OVA treated group, indicates cellular infiltration into the BALF, which was also reported by Wardlaw et al. (2000). To further confirm cellular infiltration into the BALF, we assessed the percentage of Eosinophil count (Fig 1) and lymphocytes count (Fig 2) in the blood as well as BALF of all the groups. The percentage of both eosinophil and lymphocyte count was higher in the blood than that of the BALF of all the groups, in this manner, eosinophil count was significantly $(P<0.05)$ decreased with both doses of EAC treatment as well as DEX. While lymphocyte count was significantly $(P<0.05)$ decreased with only the dose of $300 \mathrm{mg} / \mathrm{kg}$ EAC, which appeared to be more effective than $150 \mathrm{mg} / \mathrm{kg}$ EAC and DEX treated group.

Eosinophil infiltration into BALF is the basic feature of allergic asthma and it is apparent even in very mild asthmatic condition (Wengmann and Renz, 2005). Bronchoalveolar lavage fluid is a diagnostic tool for toxic substances in bronchoalveolar, asthma and chronic obstructive pulmonary diseases (COPD) (Meyer, 2007). Also, the increased lymphocyte in BALF of OVA treated group may orchestrate eosinophil inflammation, which is involved in the pathogenesis of allergic asthma (Kumari and Rana, 2012).

Both monocytes and neutrophils are not the hallmark of allergic asthma, as such their presence in large number in BALF does not confirm asthma (Wardlaw et al., 2000). However, Macrophages and neutrophils are the most numerous cells in the airways, macrophages act as antigen presenting cells and can be activated by allergens through low-affinity IgE receptors to release inflammatory mediators and cytokines that amplify the inflammation (Wenzel, 2003).

The lung histology a normal cytoachitecture of the lungs in the control group (plate 1.), the OVA group showed a marked lung inflammation associated with cellular infiltration, edema and congestion (plate 2). Groups treated with EAC at $150 \mathrm{mg} / \mathrm{kg}$ showed a mild congestion and cellular infiltration but no edema (plate 3), while $300 \mathrm{mg} / \mathrm{kg}$ Allium cepa treated group showed only a mild cellular infiltration (plate 4) and DEX group showed no cellular infiltration but mild congestion (plate 4).

Therefore, the pathological changes, which appeared in all OVA-induced animals at various degrees have confirmed the presence of allergic asthma induced by ovalbumin, Since inflammation, cellular infiltration, and edema are the hallmark of allergic asthma as stated by Suralkar and Kasture (2012) and Huang et al. (2014). The reduced lung inflammation with Allium cepa may be attributed to the anti-inflammatory property of the plant as well as structural effect on the airways.

The preliminary phytochemical investigation of Allium cepa, showed the presence of steroids, saponins, alkaloids and flavonoids (Lanzotti, 2006). Flavonoids are known to possess anti-inflammatory effects and antioxidant properties that may be responsible for anti-inflammatory and antioxidant activity (Kumar et al., 2010). The flavonoids in Allium cepa with potent anti-inflammatory effects are quercetin and kaemferol (Joskova et al., 2011; Nasri et al., 2012)

Studies have reported the anti-inflammatory response of quercetin and its inhibitory effect on muscarinic receptors in the bronchial smooth muscles cells resulting in bronchodilation, It also exerts an inhibitory effect on histamine released during all phases of allergic reactions (Joskova et al., 2011). Reports have shown that kaempferol inhibits the enzymes cyclooxygenases (COX,) Lipoxygenases (LOX) and inducible nitric oxide synthase (iNOX) (Calderón-Montaño et al., 2011). These enzymes are known to play important roles in inflammation by participating in the synthesis of eicosanoids and production of reactive species (Nasri et al., 2012).

It is concluded from this study, that aqueous extract of Allium cepa decreases the inflammatory responses of ovalbumin-induced allergic asthma in rats in a similar way compared to that of a standard antiasthma drug (dexamethasone). 
BAJOPAS Volume 9 Number 2 December, 2016

Table 1: Effects of Aqueous Extract of Allium cepa on Differential Cell Count In Blood of OvalbuminInduced Allergic Asthma In Wistar Rats Control OVA 200mg

$\begin{aligned} & \text { OVA } 200 \mathrm{mg} \\ & \text { ACP } 150 \mathrm{mg} / \mathrm{kg}\end{aligned}+\underset{\text { ACP } 300 \mathrm{mg} / \mathrm{kg}}{\text { OVA } 200 \mathrm{mg}}+\underset{\text { DEX } 1 \mathrm{mg} / \mathrm{kg}}{\text { OVA } 200 \mathrm{mg}}+$

\begin{tabular}{|c|c|c|c|c|c|}
\hline $\begin{array}{l}\text { LYMPHOCYE } \\
\text { CELLS (\%) }\end{array}$ & $28.00 \pm 0.77$ & $48.60 \pm 1.75^{a}$ & $40.60 \pm 3.16$ & $28.40 \pm 0.75^{\mathbf{b}}$ & $35.40 \pm 2.11^{\mathrm{b}}$ \\
\hline $\begin{array}{l}\text { NEUTROPHL } \\
\text { CELLS (\%) }\end{array}$ & $60.60 \pm 1.08$ & $68.60 \pm 0.51^{a}$ & $47.82 \pm 2.40^{\mathrm{a}}$ & $63.40 \pm 0.24^{b}$ & $62.60 \pm 2.75^{b}$ \\
\hline $\begin{array}{l}\text { EOSINOPHIL } \\
\text { CELLS (\%) }\end{array}$ & $3.00 \pm 0.32$ & $4.80 \pm 0.58^{\mathrm{a}}$ & $3.40 \pm 0.24^{\mathrm{a}}$ & $2.20 \pm 0.49^{b}$ & $2.60 \pm 0.57^{b}$ \\
\hline $\begin{array}{l}\text { MONOCYTE } \\
\text { CELLS (\%) }\end{array}$ & $6.40 \pm 0.51$ & $5.60 \pm 0.68^{a}$ & $6.20 \pm 0.37^{b}$ & $5.00 \pm 0.55^{\mathrm{a}}$ & $3.20 \pm 0.37^{\mathbf{b}}$ \\
\hline $\begin{array}{l}\text { BASOPHIL } \\
\text { CELLS (\%) }\end{array}$ & $0.80 \pm 0.37$ & $0.80 \pm 0.37$ & $0.60 \pm 0.40$ & $0.40 \pm 0.24$ & $0.40 \pm 0.24$ \\
\hline
\end{tabular}

Values with different superscript are significant $(\mathrm{P}<0.05)$ along a row.

Table2: Effects of Aqueous Extract of Allium cepa on Differential Cell Count In Broncho Alveolar Fluid (Balf) of Ovalbumin-Induced Allergic Asthma In Wistar Rats

\begin{tabular}{llllll}
\hline & Control & OVA 200mg & $\begin{array}{l}\text { OVA 200mg + } \\
\text { ACP 150mg/kg }\end{array}$ & $\begin{array}{l}\text { OVA 200mg + } \\
\text { ACP 300mg/kg }\end{array}$ & $\begin{array}{l}\text { OVA 200mg + } \\
\text { DEX 1mg/kg }\end{array}$ \\
\hline $\begin{array}{l}\text { LYMPHOCYTE } \\
\text { CELLS (\%) }\end{array}$ & $18.60 \pm 2.38$ & $28.40 \pm 1.03^{\mathrm{a}}$ & $17.00 \pm 1.22^{\mathrm{b}}$ & $17.00 \pm 3.18^{\mathrm{b}}$ & $17.60 \pm 1.12^{\mathrm{b}}$ \\
$\begin{array}{l}\text { NEUTROPHIL } \\
\begin{array}{l}\text { CELLS (\%) } \\
\text { EOSINOPHIL }\end{array}\end{array}$ & $6.20 \pm 0.66$ & $5.40 \pm 0.87^{\mathrm{a}}$ & $6.80 \pm 1.02^{\mathrm{b}}$ & $6.60 \pm 0.51^{\mathrm{b}}$ & $6.40 \pm 0.68^{\mathrm{b}}$ \\
$\begin{array}{l}\text { CELLS (\%) } \\
\text { MONOCYTE } \\
\text { CELLS (\%) }\end{array}$ & $0.80 \pm 0.37$ & $2.80 \pm 0.37^{\mathrm{a}}$ & $0.80 \pm 0.37^{\mathrm{b}}$ & $0.80 \pm 0.37^{\mathrm{b}}$ & $0.60 \pm 0.40^{\mathrm{b}}$ \\
\hline
\end{tabular}

Values with different superscript are significant $(P<0.05)$ along a row. 


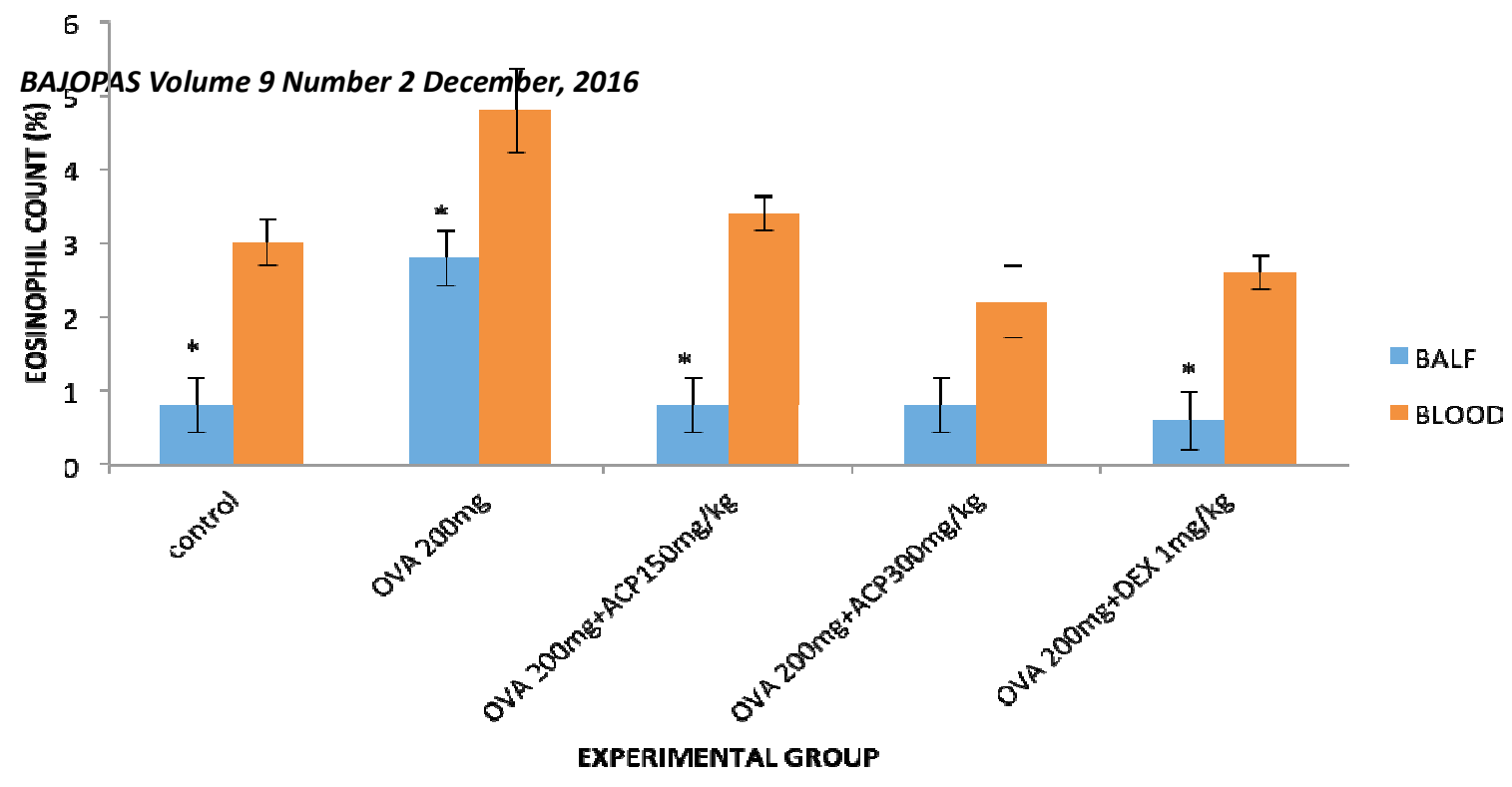

Fig 1: The Effects of Aqueous Extract of Allium cepa on percentage of Eosinophil Count In Blood And Balf of Ovalbumin-Induced Allergic Asthma In Wistar Rats

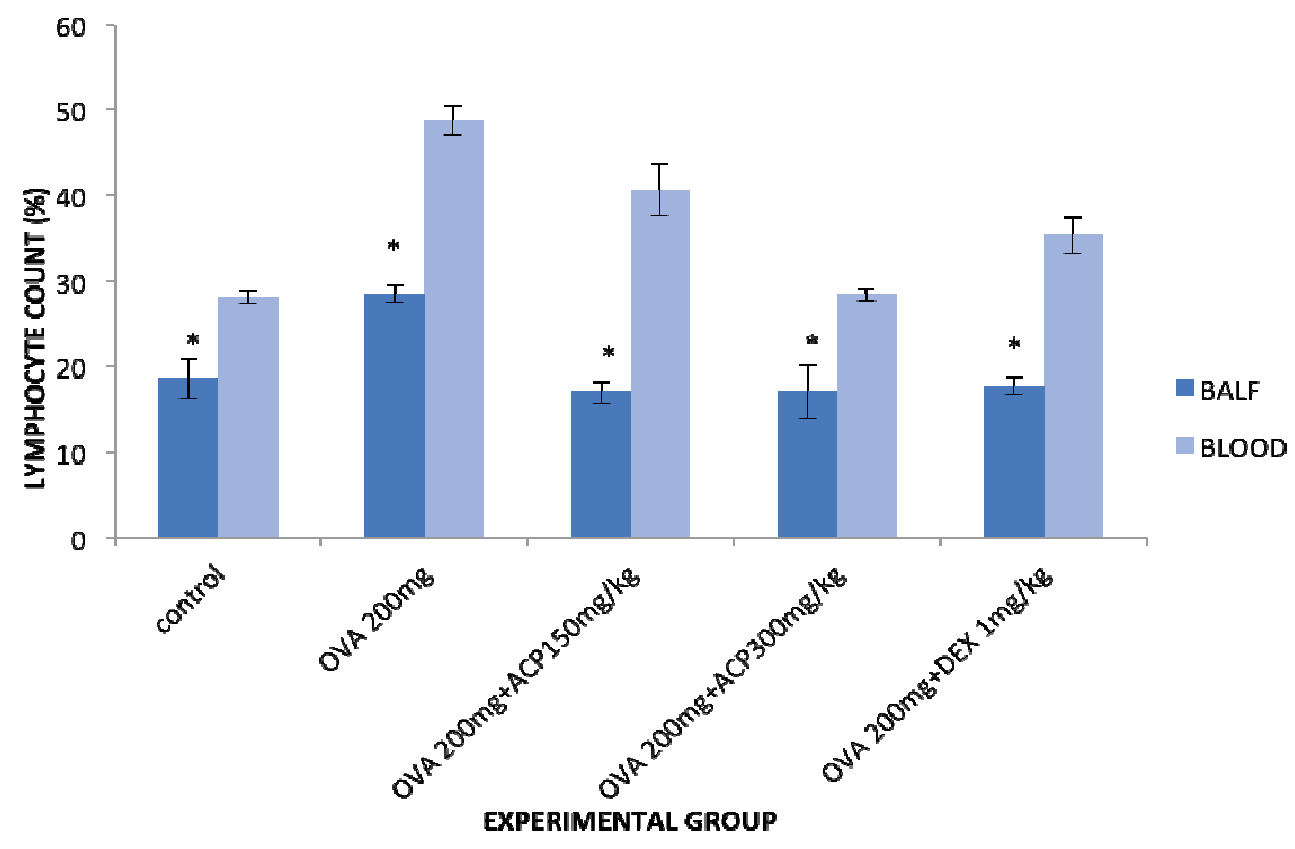

Fig 2: The Effects of Aqueous Extract of Allium cepa on percentage of lymphocytes Count In Blood and BALF of Ovalbumin-Induced Allergic Asthma In Wistar Rats 


\section{Histological analysis}

The slides in plates 1-5 showed the histological changes on the effect of Aqueous Extract of Allium Cepa on Lung Histology of Ovalbumin-Induced Allergic Asthma In Wistar Rats.

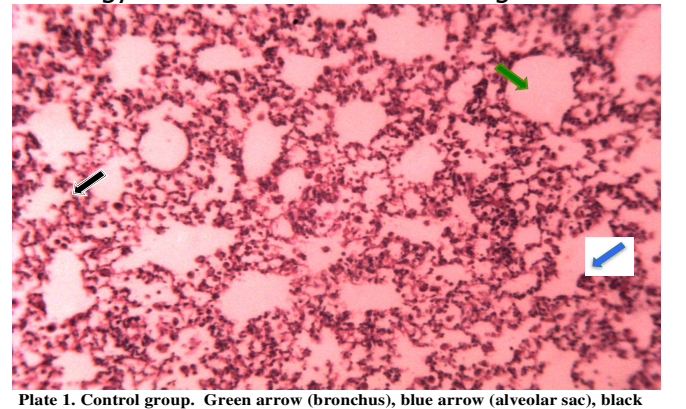
Plate 1. Control group. Green arrow (bronchus), blue arrow (alveolar sac), black
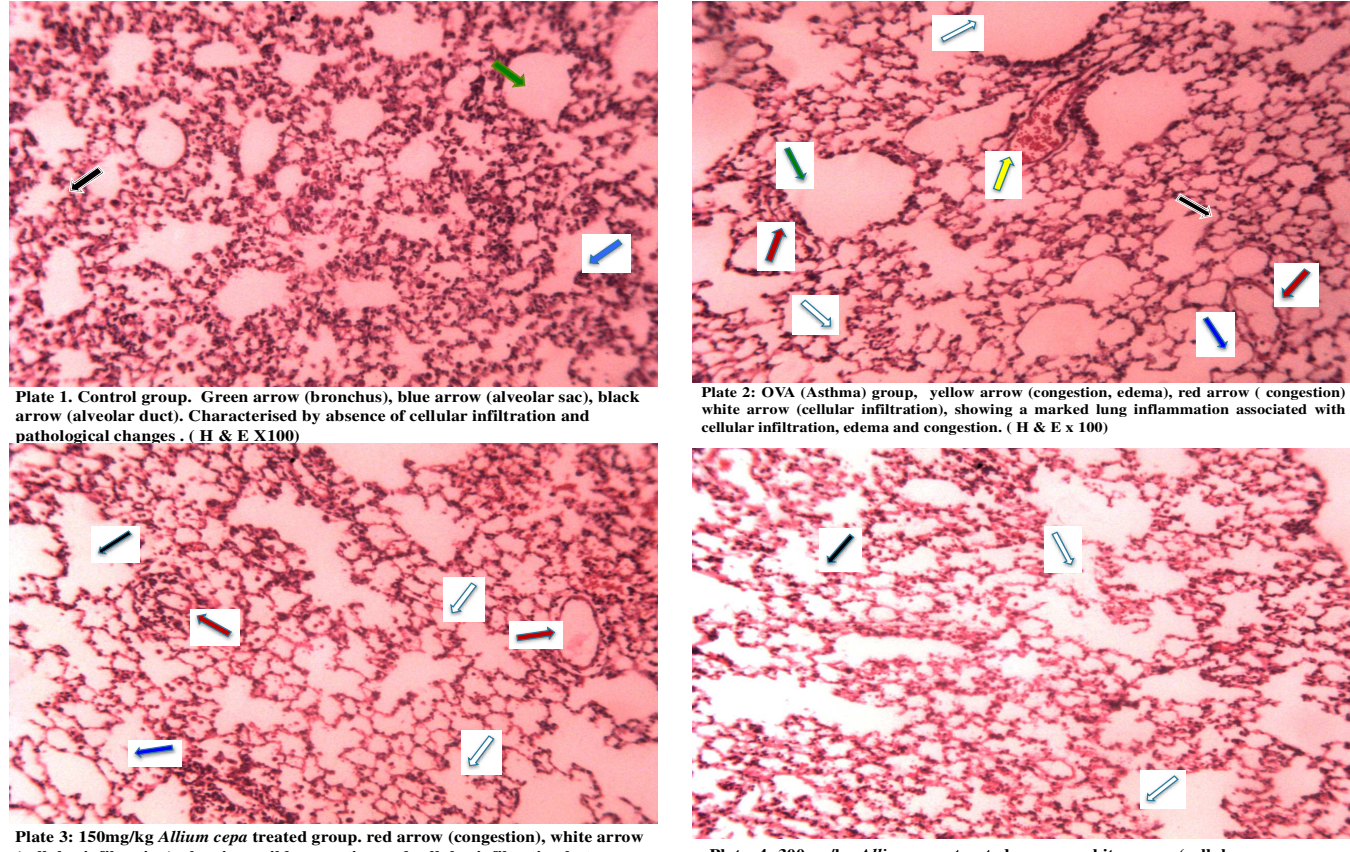
white arrow (cellular infiltration), showing a marked lu
cellular infiltration, edema and congestion. ( H \& E x 100)

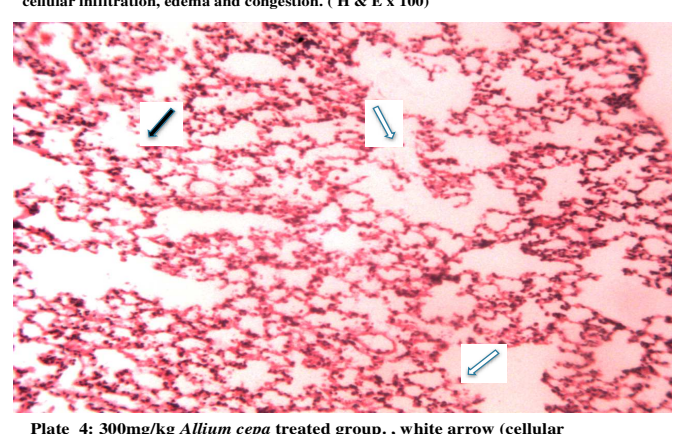

(cellular infiltration),

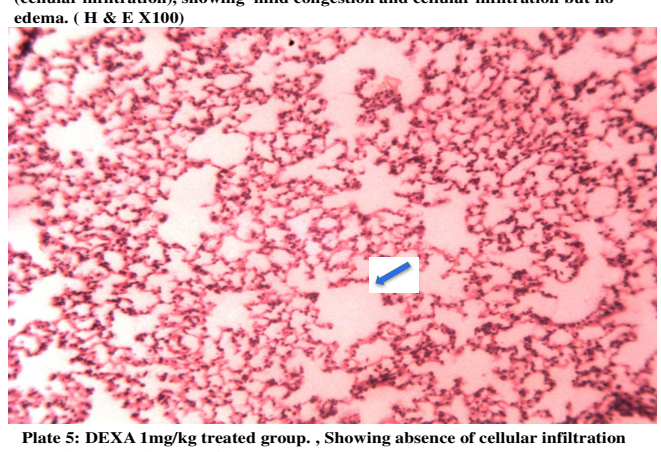

\section{Contribution of Authors}

F.A Dawud: Experimental design, practical experiment and manuscript preparation

A. B. Dabo: practical experiment, result preparation , photomicroscopy

N. W Yusuf: Statistical analysis and manuscript preparation

I .A. Umar: Idea of the experiment, manuscript editing.

Conflicts of interest

\section{References}

Agbonon, A., Aklikokou, K., Eklu-Gadegbe, K., Akpagna, K. and Gbeassor, M., (2005). Effect of ethanolic extract of pluchea ovalis root in asthma model of wistar rat; Boletin Latinoamericano y del caribe de plantas medicinales y Aromaticas, 4 (3): 52-7

Calderon-Montano, J. M., Burgos-Moron, E., PerezGuerrero, C. and Lopez-lazaro, M., (2011). A

The authors declare that there is no conflict of interests in the publication of this paper.

\section{Acknowledgements}

The authors thank the Ahmadu Bello University, Zaria, Kaduna State, Nigeria for supporting this project. The authors would also like to thank Mr peter S. Akpulo of the Histology Unit of Human Anatomy Department, Faculty of Medicine, Ahmadu Bello University, Zaria, Kaduna State, Nigeria.

review on the dietary flavonoid Kaemferol; Mini-review in medicinal chemistry, 11: 298344

Chaudhari, B., Jagdele, P., Raissudin, S., Thiparti, S. S., Shukla, M. and Singh, K.P., (2011). Histological studies of murine model of asthma; Journal of Applied Pharmaceutical Sciences, 1(10): 77-84 
Ghalehkandi, J. G., Baheshti, R., Maheri Sis, N. and Ghorbai, A., (2012). Androgenic effect of onion extract on sperm quantity and viability compared with zinc sulphate supplementation in rats; Asian Journal of Experimental Biological Science, 3 (3): 506509

Huang, X. P., Tao, E. X., Feng, Z, Q., Yang, Z. L. and Zhang, W. F., (2014). Inhibitory effect of sihuangxiechai decoction on ovalbumininduced airway inflammation in guinea pig; Hidawi publishing cooperation, 2014: 8-16

Joskova, M., Franova, S. and Sadlanova, V., (2011). Acute bronchodilator effect of Quercetin in Experimental asthma; Bratis/ Lek Listy,112 (1): $9-12$

Kucharewicz, I., Lukaszyk, A. B. and Buczko, W., (2008). Experimental asthma in rats; pharmacological report; Polish Academy of Science, 60: 783-788

Kumar, K. P. S., Bhowmik, D., Biswajit, C. and Tiwari, p., (2010). A traditional medicinal herb and its health benefits; Journal of Chemical and pharmacological Research, 2(1): 283-291

Kumari, K. and Rana, A. C., (2012). A review on epidemiology, pathology and management of asthma; Journal of Applied Pharmaceutical Sciences, 2 (7): 55-64

Lanzotti, V., (2006). The analysis of onion and garlic; Journal of Chromatography, 11(12): 213-220

Lewis, S. M., Bain, B. J., Bates, I., Dacie, L., (2009). Practical Hematology. 9th Edition. Churchill Livingstone

Manohor, S. and Selvakuman, J., (2012). Estimation of serum immunoglobulin $\mathrm{E}$ level in allergic asthma and allergic rhinitis patients before and after treatment; European Journal of Experimentlal Biology, 2 (6): 2199-2205

Meyer KC. (2007). Bronchoalveolar lavage as a diagnostic tool. Seminar Respiratory Critical Care Medicine, 28:546-60.

Mitchell, D.M., Gildehh, P., Dimond, A.H and Colloins J.V., (2007). Value of serial peak expiratory flow measurements in assessing treatment response in chronic airflow limitation; International Journal of Respiratory Medicine, $41(8) ; 606-610$

Moffet, J. R., and Namboodiri, M. A. (2003). Tryptophan and immune response. Immunology Cell Biology, 81:247-65

Musa, B. M., and Aliyu, M. D. (2014). Asthma prevalence in Nigerian adolescentsand adults: systematic review and metaanalysis. African Journal of Respiratory Medicine, 10 (1) 4-9

Nasri, S., Anush, M. and Khatami, N., (2012). Evaluation of analgesic and antiinflammatory effects of fresh onion juice in experimental animals; African Journal of
Pharmacy and Pharmacology, 6 (23): 16791684

Ogunmodede, O.S., Saalu, L.C., Ogunlade, B., Akunna, G.G. and Oyewopo, A.O., (2012). An evaluation of the hypoglycaemic, antioxidant and hepatoprotective potentials of onion on alloxan-induced diabetic Rabbits; International Journal of Pharmacology, 8: 21-29

Ozougwu, J. C. and Eyo, J. E., (2014). Hepatoprotective effects of allium cepa extracts against paracetmol-induced liver damage in rats; African Journal of Biotechnology, 13(26): 2679-2688

Pauluhn, J., Woolhiser, M. R., and Bloeman, L., (2005). Repeated inhalation challenge with diphenylmethane-4,4-Diisocyanate in brown Norway rats; Inhalation Toxicology, 17: 6778

Russo M, Nahori, M. A., Lefort, J., Gomes, E., Keller, A. C., Rodriguez, D., Ribeiro, O. G., Adriouch, S., Gallois, V., de Faria, A.M. C. and Vargaftig, B.B. (2001). Suppression of asthma-like responses in different mouse strains by oral tolerance. American Journal of Respiration. Cell Molecular Biology, 24 : 518-526.

Salama, A.A., Zaki, H. F., Shenawy, S. M., El-Denshey, E. S., Ismaiel, K. I. and Shaffie, N. M., (2012). Effects of fish oil and dexamethasone in experimentally induced bronchial asthma; Austrian Journal of Basic and Applied Sciences, 6 (13): 496-506

Suralkar, A.A and Kasture, S.B., (2012). Inhibitory effectof aabrus precatoriuos extract on bronchial hyperactivity induced by ovalbumin in experimental animals; International Journal of pharmacy and pharmaceutical sciences, 5(1): 403-409

Wardlaw, A, J., Brightling, C., Green, R., Woltmann, G. and Pavord, I., (2002). Eosinophil in asthma and other allergic diseases; British Medical Bulletin, 56 (4): 985-1003

Wardlaw, A, J., Brightling, C., Green, R., Woltmann, G. and Pavord, I., (2002). Eosinophil in asthma and other allergic diseases; British Medical Bulletin, 56 (4): 985-1003

Wengmann, M. and Renz, H., (2005). Animal model of experimental asthms; Ernst schevang Respiratory Foundation, 50: 69-87

Wenzel, S., (2003). Mechanisms of severe asthma. Clinical and Experimental Allergy, 129: 390396

Zhang, X. Y., Simpson, J. L., Powell, H., Yang, I. A., Upham, J. W., Reynolds, P. N., Hodge, S., James, A. L., Jenkins, C., Peters, M. J., Lin, J.T., and Gibson, P.G. (2014). Full blood count parameters for the detection of asthma inflammatory phenotypes. Clinical and Experimental Allergy, 44 (9): 1137-45. 